http://www.jfas.info

\title{
ISOLATION AND MOLECULAR CHARACTERIZATION OF PHYTASE PRODUCING BACTERIA FROM MALAYSIA HOT SPRINGS
}

\author{
N. Alias ${ }^{*}$, S. Shunmugam and P. Y. Ong \\ School of Agriculture Science and Biotechnology, Faculty of Bioresources and Food Industry, \\ Universiti Sultan Zainal Abidin, 22200 Besut, Terengganu, Malaysia
}

Published online: 08 August 2017

\begin{abstract}
Potential phytase producing bacterial were isolated from different hot springs in Malaysia which were Labis (Johor), Dusun Tua (Selangor), Ulu Legong (Kedah) and Ranau (Sabah). All bacterial samples were grown in Phytase Screening Media (PSM) at temperatures of $37^{\circ} \mathrm{C}, 45^{\circ} \mathrm{C}, 50^{\circ} \mathrm{C}$ and $55^{\circ} \mathrm{C}$ for four days. Out of all samples tested, five isolates have showed clearing zone surrounding the colony which indicates presence of phytase activity. The strains were further analyzed in broth culture using sodium phytate as substrate. Among them, strain L3 was selected as the best producer $(0.16 \mathrm{U} / \mathrm{ml}$ after $72 \mathrm{~h}$ of culture $)$. This phytase showed optimal activity at $37^{\circ} \mathrm{C}$ and $\mathrm{pH} 5.5$, demonstrating appropriate character for application in feed of several industrial processes. Blast homology of 16S rRNA gene sequence of isolate L3 identified 99\% similarity to Acinetobacter baumannii.
\end{abstract}

Keywords: Acinetobacter baumannii; phytase; phytic acid.

Author Correspondence, e-mail: nadiawati@unisza.edu.my

doi: http://dx.doi.org/10.4314/jfas.v9i2s.53

\section{INTRODUCTION}

Phytate is an anhydrous salt form of phytic acid which is the major storage form of phosphorus and inositol in plants seeds. Phytate capable of producing $65-80 \%$ of the total 
phosphate in grains [1] and up to $80 \%$ of total phosphate in manures from monogastric animals [2]. They are strongly complexed in soils, representing a vital class of organic phosphate [3]. Phytate degradation is mediated by an enzyme, phytase to release the phosphate ions [4]. This enzyme is a type of phosphatases which hydrolyses phytate to a series of myo-inositol phosphate derivatives and inorganic phosphate [5]. Phytases are widespread in nature and can be found in microorganisms, plants, fungi, yeast as well as in some animal tissues [6]. Phytase producing microorganism can be found abundantly in rhizospheric soil of crop plants such as Aspergillus ficuum [7], Escherichia coli [8] and Bacillus subtilis [9]. According to some studies, microbial phytases are most promising for biotechnology application [10]. Based on a study by [3], although the commercial productions of phytases are more focused on the fungus Aspergillum, there are some studies suggested bacterial phytases can be an alternative to the fungal phytases due to their higher specificity, greater resistance to proteolysis and better catalytic efficiency. These bacteria are of interest for biotechnology application such as improving animal feed [11] and also used as soil inoculants to increase phosphate uptake by plants [12]. Currently, microbial phytases has been extensively used as feed additives in diets for swine and poultry to enhance the utilization of plant based feed [13]. Nowadays, there is no single phytase that is able to meet the diverse needs for all commercial and environmental applications [14-15]. Therefore, there is an ongoing interest in screening microorganisms, including bacteria for novel phytases and also phytases play significant role in improving the nutritive quality of food and feed that contain phytic acid.

\section{RESULTS AND DISCUSSION}

\subsection{Isolation of Phytase Producing Bacteria}

Bacterial samples were isolated from different hot spring in Malaysia such as Ranau (Sabah), Ulu Lengong (Kedah), Dusun Tua (Selangor) and Labis (Johor). The bacterial samples were screened for positive phytase producer by plating the bacteria on Phytase Screening Media (PSM), which contains sodium phytate as a source of phytate to the bacteria [16]. Bacteria strains which are capable to form a halo zone onto the surrounding medium were counted as a phytase producing bacteria. Out of all bacteria strains screenced, only five strains (Strains A, 
B, D3, RT and L3) forms halo zone on the surrounding media after 4 days of incubation at 37 ${ }^{\circ} \mathrm{C}$ showing positive results as phytase producer. During plate screening for extracellular phytase-degrading ability on PSM agar media, Strain B and Strain L3 were found to be better strains that produced approximately $32 \mathrm{~mm}$ clear halo zones around the colonies on fourth day of incubation (Fig. 1).
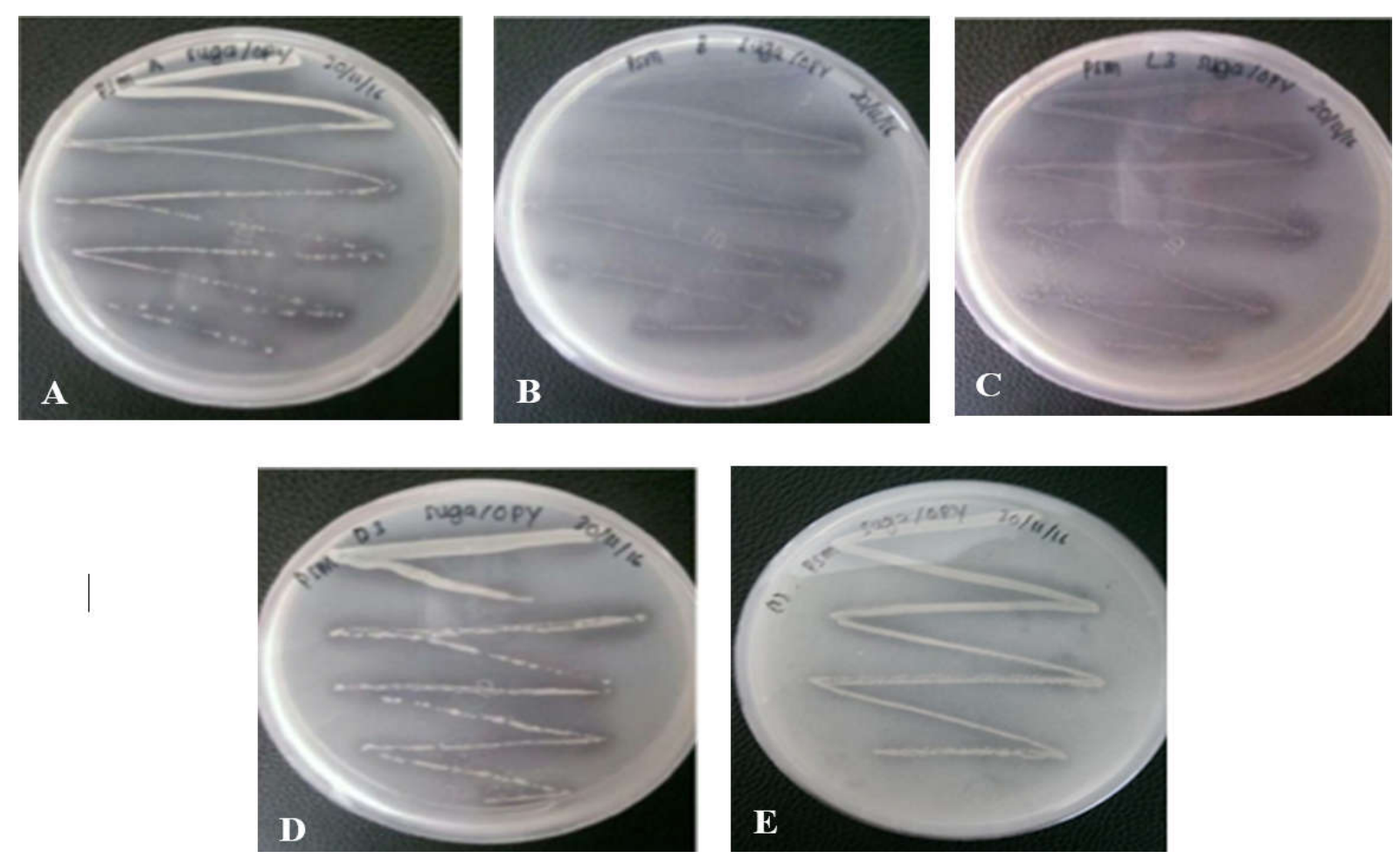

Fig.1. Five isolated strains forming halo regions after streaking on Phytase Specific Agar medium. A; Strain A, B; Strain B, C; Strain L3, D; Strain D3, E; Strain RT

Purified strains were examined under microscope for colony morphology (Table 1) and gram staining (Fig. 2). All the five strains were found to be gram negative bacteria as it retains the pink colour of safranin. Gram negative bacteria are made up of a thin peptidoglycan layer and also lipopolysachharide layer where the purple colour of crystal violet stain can be easily washed off and counter stained with pink. Colony morphology was analyzed using three important features according to Bergey's Manual of Systematic Bacteriology [17] which are form, elevation and margin. The colonies were categorized as shown in the Table 1. Based on the results from biochemical tests (Table 2), all bacteria strains showed the same results on biochemical tests with catalase positive, non motile, negative for oxidase, indole, $\mathrm{H}_{2} \mathrm{~S}$ production, methyl red, voges-proskauer and urease test. Triple sugar iron (TSI) indicates test for fermentation of lactose, glucose and sucrose. For Strain A and Strain B, TSI test were acidic 
whereas Strain D3, Strain L3 and Strain RT were alkali. Strain A and Strain B shows that lactose is not fermented, but there small amount of glucose fermented and the oxygen deficient slant will turn yellow. Strain D3, Strain L3 and Strain RT were alkaline because neither lactose, glucose of sucrose was fermented nor the slants turn into deep red or purple. All strains showed positive growth on Mac Conkey Agar which indicate gram negative bacteria strains. This finding was supported by the gram stain result as showed in Fig. 2.

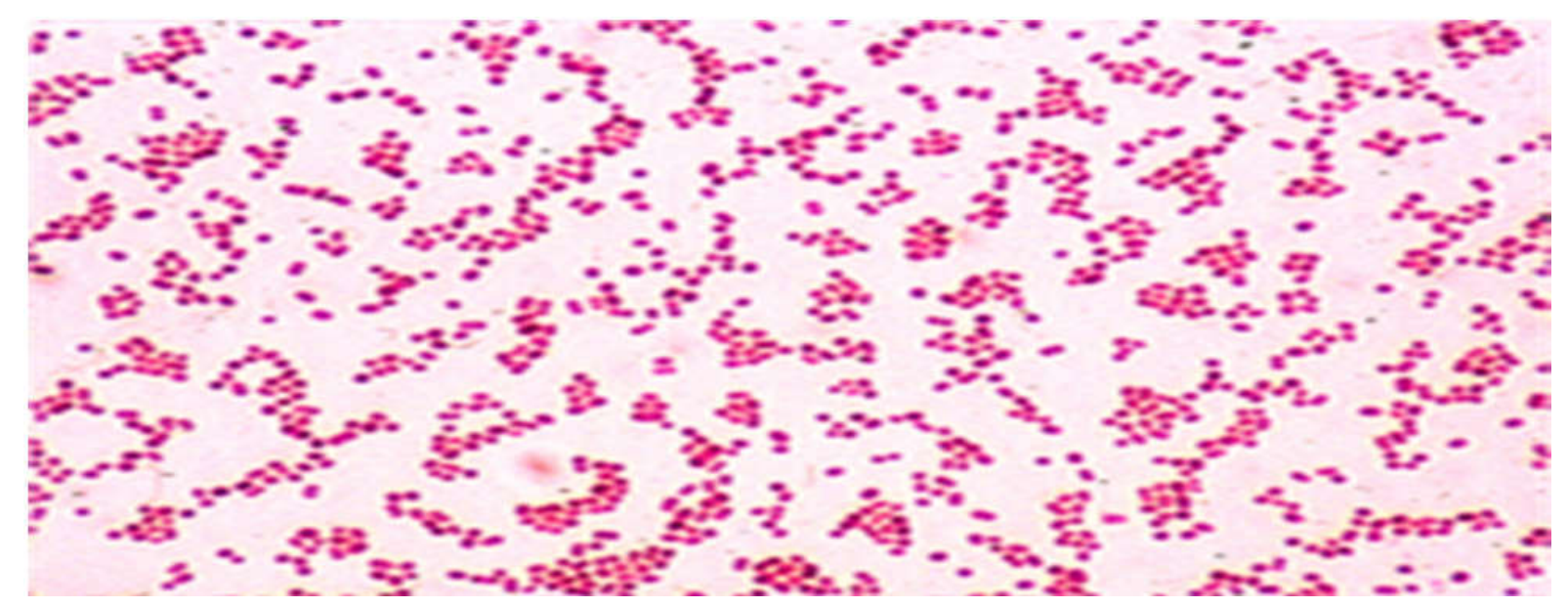

Fig.2. Gram staining results from the bacterial isolates at 1000X magnification

Table 1. Source, colony morphology and phytase production of the isolates

\begin{tabular}{ccccccc}
\hline $\begin{array}{c}\text { Bacterial } \\
\text { Isolate }\end{array}$ & $\begin{array}{c}\text { Source of } \\
\text { Isolation }\end{array}$ & \multicolumn{2}{c}{ Colony Morphology* } & Gram & Presence of \\
\hline A & Ulu & Circular & Raised & Entire & Gram negative & + \\
& Legong & & & & coccobacilli & \\
B & Ulu & Irregular & Flattened & Undulate & Gram negative & ++ \\
& Legong & & & & coccobacilli & \\
L3 & Labis & Irregular & Flattened & Undulate & Gram negative & ++ \\
& & & & & coccobacilli & \\
D3 & Dusun & Circular & Raised & Entire & Gram negative & + \\
& Tua & & & & coccobacilli & \\
RT & Ranau & Irregular & Raised & Undulate & Gram negative & + \\
& & & & & coccobacilli & \\
\hline
\end{tabular}

- Characteristics are based on Bergey’s Manual of Systematic Bacteriology [17]. 
Table 2. Biochemical characteristics of five bacteria isolates

\begin{tabular}{cccccc}
\hline Biochemical Tests & & & Bacteria Isolates & \\
& A & B & L3 & RT & D3 \\
\hline Catalase & + & + & + & + & + \\
Oxidase & - & - & - & - & - \\
Motility & Non & Non & Non & Non & Non \\
& motile & motile & motile & motile & motile \\
Indole & - & - & - & - & - \\
H 2 production & - & - & - & - & - \\
Methyl Red & - & - & - & - & - \\
Voges-Proskauer & - & - & - & - & - \\
Urease & - & - & - & - & Alkali \\
Acid from TSI & Acid & Acid & Alkali & Alkali & + \\
\hline Growth on Mac Conkey agar & + & + & + & + & +
\end{tabular}

\subsection{Phytase Assay and Optimum Conditions}

Quantitative screening for phytase assay was done using supernatant from all isolates. The assay was carried out by growing bacterial strains in liquid medium containing sodium phytate as the substrate. Two types of liquid PSM media were prepared, one with $1 \%$ peptone and the other without $1 \%$ peptone. After three days of incubation at $37{ }^{\circ} \mathrm{C}$, phytase assay was determined by measuring amount of liberated inorganic phosphates [16].

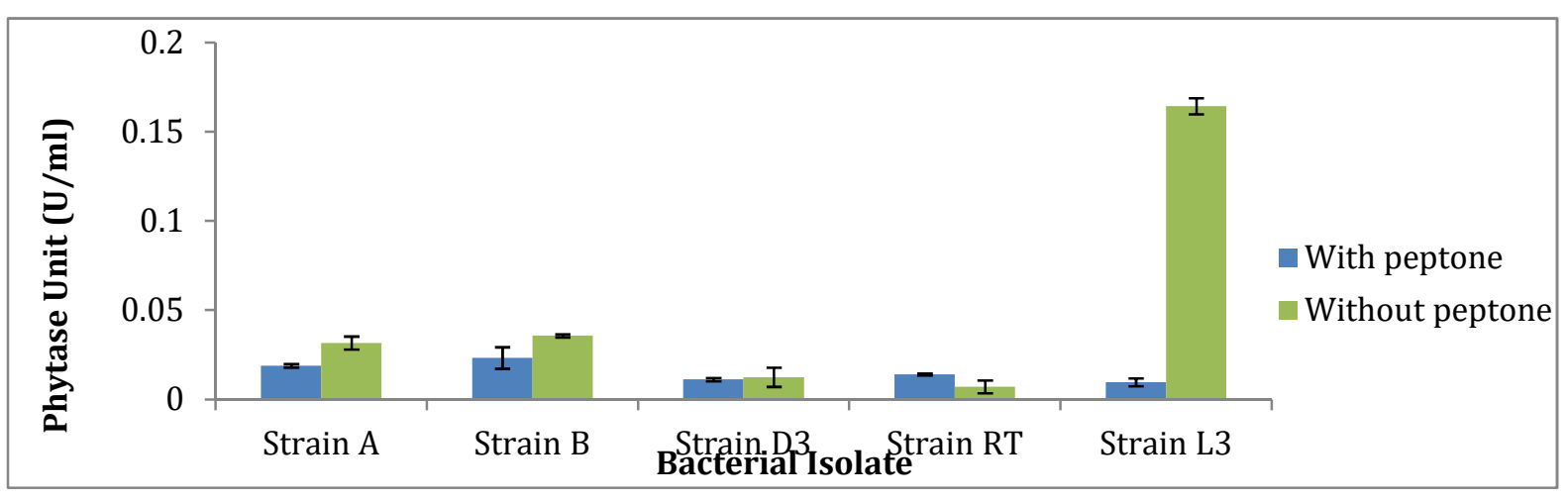

Fig.3. Phytase activity from five bacterial isolates in PSM media with peptone and without peptone

Coherence between phytase production and bacterial growth on PSM medium was noticed when both parameters reached their peak on the third day at $37{ }^{\circ} \mathrm{C}$. Bacteria strain $\mathrm{L} 3$ release 
maximum phytase activity $(>0.16 \mathrm{U} / \mathrm{ml})$, while bacteria strain RT showed the lowest phytase activity at $0.007 \mathrm{U} / \mathrm{ml}$ after third day of incubation in media without peptone. The highest phytase activity for media with the addition of peptone was observed by Strain B which at 0.023 $\mathrm{U} / \mathrm{ml}$ of phytase activity. This activity was considered low as compare to the same bacteria in media with peptone with activity at $0.036 \mathrm{U} / \mathrm{ml}$. We can conclude that all bacteria strains showed reduced phytase activity in media with the addition of peptone as compare to the media without peptone as showed in Fig. 3.

\subsection{Molecular identification of the selected bacteria isolate}

Genomic DNA of the putative bacteria strain L3 was isolated using Wizard Genomic DNA Extraction Kit (Promega) before evaluated on 1\% agarose gel electrophoresis. After PCR amplification, with the help of universal primers of $16 \mathrm{~S}$ rRNA, single discrete PCR product was observed at approximately $1.5 \mathrm{~kb}$ of size (Fig. 4).

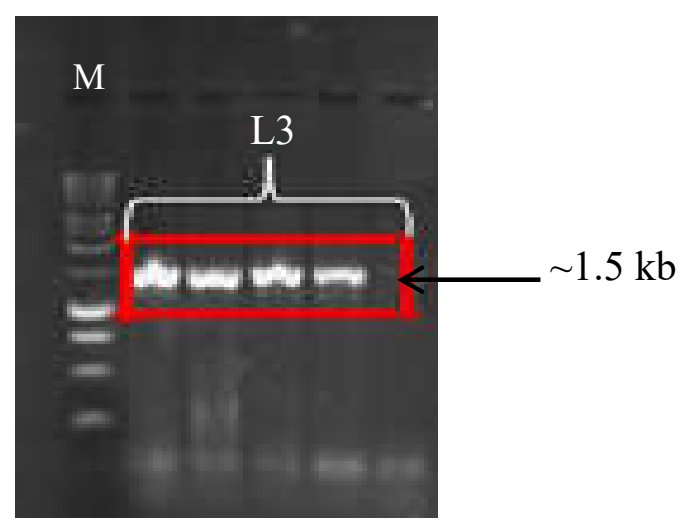

Fig.4. PCR amplification products of 16S rRNA from bacteria strain L3. PCR producs with approximately $1.5 \mathrm{~kb}$ on $1 \%$ agarose gel. M: $1 \mathrm{~kb}$ DNA ladder (Promega)

BLAST homology (Fig. 5) comparison analysis of 16S rRNA region of the DNA sequences from strain L3 (Fig. 6) revealed 99\% similarity to Acinetobacter baumannii, and thus the molecular identity of the isolate was confirmed. Bacteria strain L3 also showed the same observation for catalase positive, oxidase negative, non-motile, ability to utilize some substrates which was in agreement with [18] on the identification of Acinetobacter baumannii strains. Furthermore, phylogenetic tree (Fig. 7) based on 16S rRNA gene sequence using neighbour joining tree method, a powerful tool for deducing evolutionary and phylogenetic relationships among the organisms was decisive in their identification. 
if Alignments

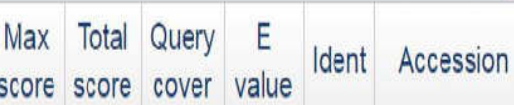

Acinetobacter baumannil strain DSM 30007 16S ribosomal RNA gene, partial sequence $351 \quad 351 \quad 82 \% \quad 6 e-97 \quad 99 \% \quad$ NR 117677.1 Acinetobacter baumannii strain ATCC 1960616 S ribosomal RNA gene, complete sequence $351 \quad 351 \quad 82 \% \quad 6 e-97 \quad 99 \% \quad$ NR_ 117620.1

Acinetobacter baumannii strain JCM $684116 S$ ribosoma RNA gene, partial sequence $351 \quad 351 \quad 82 \% \quad 6 e-97 \quad 99 \% \quad$ NR_113237.1

Acinetobacter baumannii strain $\mathrm{ClP} 70.3416$ S ribosomal RNA gene, partial sequence Acinetobacter baumannil strain ATCC 1960616 S ribosomal RNA gene. parial sequence Acinetobacter baumannii strain DSM 30007 16S ribosomal RNA gene, partial sequence Acinetobacter nosocomialis strain RUH 237616 s ribosomal RNA gene, partial sequence $351 \quad 351 \quad 82 \% \quad 6 e-97 \quad 99 \% \quad$ NR 116845.1 $351 \quad 351 \quad 82 \% \quad 6 e-97 \quad 99 \% \quad$ NR_ 119358.1 $351 \quad 351 \quad 82 \% \quad 6 e-97 \quad 99 \% \quad$ NR 026206.1 Acinetobacter antiviralis strain KNF2022 16 S ribosomal RNA gene, partal sequence $333 \quad 333 \quad 82 \% \quad 2 e .91 \quad 98 \% \quad$ NR_ 117931.1 Acinetobacter Ivoffi strain DSM 240316 S ribosomal RNA gene, partial sequence $324 \quad 324 \quad 82 \% \quad 1$ e- $88 \quad 97 \% \quad$ NR_ 115739.1 Acinetobacter INoffi strain JCM 684016 S ribosomal RNA gene, partial sequence $318 \quad 318 \quad 82 \% \quad 6 e-87 \quad 96 \% \quad$ NR__026209.1 $316 \quad 316 \quad 82 \% \quad 2 \mathrm{e}-86 \quad 96 \% \quad$ NR_113346.1

Fig.5. BLAST homology comparison of $16 \mathrm{~S}$ rRNA from bacteria strain L3 against NCBI database

1 agagtttgat catggctcag attgaacgct ggcggcaggc ttaacacatg caagtcgagc

61 gggggaaggt agcttgctac cggacctagc ggcggacggg tgagtaatgc ttaggaatct

121 gcctattagt gggggacaac atctcgaaag ggatgctaat accgcatacg tcctacggga

181 gaaagcaggg gatcttcgga ccttgcgcta atagatgagc ctaagtcgga ttagctagtt

241 ggtggggtaa aggectacca aggegacgat ctgtagcggg tctgagagga tgatccgcca 301 cactgggact gagacacgge ccagactcct acgggaggca gcagtgggga atattggaca 361 atggggggaa ccetgatcca gecatgccge gtgtgtgaag aaggecttat ggttgtaaag 421 cactttaagc gaggaggagg ctactttagt taatacctag agatagtgga cgttactcgc 481 agaataagca ccggetaact ctgtgecagc agccgcggta atacagaggg tgcgagcgtt 541 aatcggattt actgggcgta aagcgtgcgt aggcggctta ttaagtcgga tgtgaaatcc 601 ccgagcttaa cttgggaatt gcattcgata ctggtgagct agagtatggg agaggatggt 661 agaattccag gtgtagcggt gaaatgcgta gagatctgga ggaataccga tggcgaaggc 721 agccatctgg cctaatactg acgctgaggt acgaaagcat ggggagcaaa caggattaga

781 taccetggta gtccatgccg taaacgatgt ctactagccg ttggggectt tgaggcttta 841 gtggcgcage taacgcgata agtagaccge ctggggagta cggtcgcaag actaaaactc 
901 aaatgaattg acgggggecc gcacaagcgg tggagcatgt ggtttaattc gatgcaacgc

961 gaagaacctt acctggectt gacatactag aaactttcca gagatggatt ggtgecttcg

1021 ggaatctaga tacaggtgct gcatggctgt cgtcagctcg tgtcgtgaga tgttgggtta

1081 agtcccgcaa cgagcgcaac cettttcett acttgccagc atttcggatg ggaactttaa

1141 ggatactgcc agtgacaaac tggaggaagg cggggacgac gtcaagtcat catggccett

1201 acggccaggg ctacacacgt gctacaatgg tcggtacaaa gggttgctac acagcgatgt

1261 gatgctaatc tcaaaaagcc gatcgtagtc cggattggag tctgcaactc gactccatga

1321 agtcggaatc getagtaatc geggatcaga atgccgcggt gaatacgttc ccgggecttg

1381 tacacaccgc ccgtcacacc atgggagttt gttgcaccag aagtagctag cctaactgca

1441 aagagggcgg ttaccacggt gtggecgatg actggggtga agtcgtaaca aggtagccgt

1501 aggggaacet geggetggat cacctcctt

Fig.6. The 16S rRNA gene sequence of bacteria strain L3 at 1579 bp

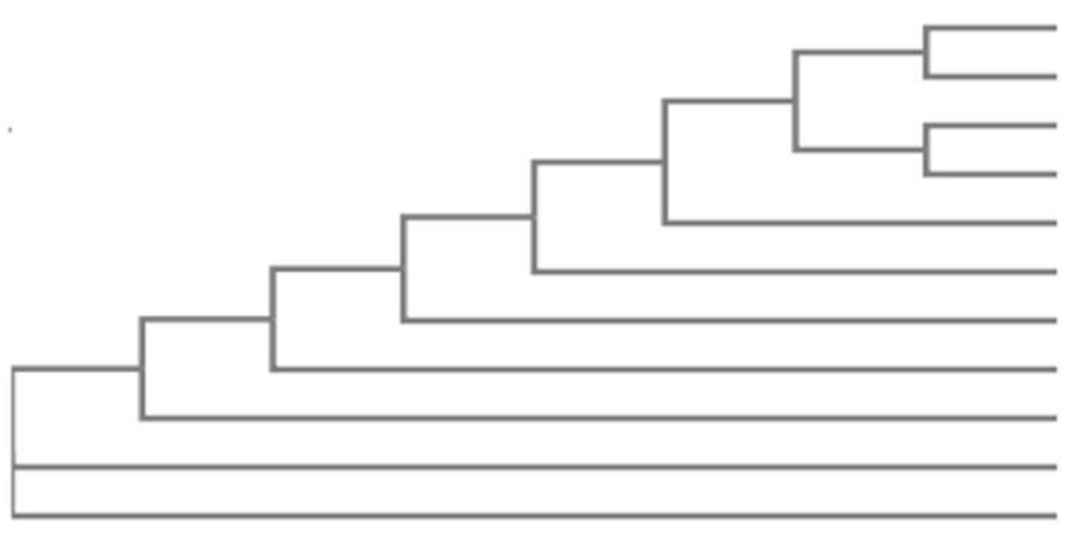

NR_026209.10.00071

NR_113346.1 0.00204

NR_117931.1 0.00961

NR_042387.1 0.00621

NR_115739.1 0.01209

NR_119358.1 0.00123

NR_116845.10

NR_117677.10

NR_113237.10

NR_026206.10

L3 0

Fig.7. Phylogenetic tree based on $16 \mathrm{~S}$ rRNA gene sequence showing relationship between bacteria strain L3 and ten related members of Acinetobacter. NR_026209.1; A. lwoffii strain DSM 2403, NR_113346.1; A. lwoffii strain JCM 6840, NR_117931.1; A. nosocomialis strain RUH 2376, NR_042387.1; A. calcoaceticus strain NCCB 22016, NR_115739.1; A. antiviralis strain KNF2022, NR_119358.1; A. baumannii strain ATCC 19606, NR_116845.1; $A$. baumannii strain CIP 70.34, NR_117677.1; A. baumannii strain DSM 30007, NR_113237.1; A. baumannii strain JCM 6841; NR_026206.1; A. baumannii strain DSM 30007

\section{EXPERIMENTAL}




\subsection{Samples Collection}

Samples were collected from four different places in hot spring in Malaysia which were Ranau (Sabah), Ulu Lengong (Kedah), Dusun Tua (Selangor) and Labis (Johor). At each site, about 1 $\mathrm{ml}$ of each water sample recovered by sterile syringe was transferred to each of the bottles, consisting of $10 \mathrm{ml}$ media in a $30 \mathrm{ml}$ sterilizes universal bottles. The sampling was conducted in triplicates. All samples were sent to the laboratory within a period of three hours before inoculation was done.

\subsection{Isolation and Identification of Microorganisms from Hot Spring}

Nutrient broth and nutrient agar were used for isolation of microorganism from the hot spring. One milliliter sample from of each waters was added to nutrient broth $(10 \mathrm{ml})$ and incubated in water bath at $37^{\circ} \mathrm{C}, 45^{\circ} \mathrm{C}, 50{ }^{\circ} \mathrm{C}, 55^{\circ} \mathrm{C}$ and $60{ }^{\circ} \mathrm{C}$ for 4 days. Growth was followed by measuring the increase in turbidity at $600 \mathrm{~nm}$. Then, the culture was streaked onto a nutrient agar plate. Isolation of pure culture was done by using spread plate method and streak plate method recommended by [19]. The pure cultures were maintained on nutrient agar slants at 4 ${ }^{\circ} \mathrm{C}$ for further use.

\subsection{Growth and Screening for Phytase Producing Bacteria}

Aliquots $(0.1 \mathrm{~mL})$ of pure isolates of actinobacteria were cultured on Phytase Screening Medium (PSM; g/L) (g/L) Glucose, 20.0; sodium phytate, 4.0; $\mathrm{CaCl}_{2} .2 \mathrm{H}_{2} \mathrm{O}, 2.0 ; \mathrm{NH}_{4} \mathrm{NO}_{3}, 5.0$; $\mathrm{KC} 1,0.5 ; \mathrm{MgSO}_{4} .7 \mathrm{H}_{2} \mathrm{O}, 0.5 ; \mathrm{FeSO}_{4} .7 \mathrm{H}_{2} \mathrm{O}, 0.01$ and agar, 15.0. The $\mathrm{pH}$ of PSM media was adjusted to $\mathrm{pH} 5.5$ using $\mathrm{NaOH}$ [20-21]. All samples were incubated at $37{ }^{\circ} \mathrm{C}$ for 4 days. Colonies capable of hydrolysing Na-phytate showed clear halo zones against an opaque colour of non-hydrolyzed medium. The halo and colony diameters were measured after 4 days of incubation at $37^{\circ} \mathrm{C}$. Positive isolates were tested again for confirmation.

\subsection{Phytase Assay}

For phytase assay, the liquid Phytase Screening Medium (PSM) was used to grow the bacterial strains. There were two types of liquid PSM used which were with addition of peptone and without addition of peptone to compare the phytase production by bacterial strains. The bacterial strains were grown in $10 \mathrm{ml}$ of liquid PSM with peptone and $10 \mathrm{ml}$ of liquid PSM without peptone respectively in a $50 \mathrm{ml}$ centrifuge tube. Then, they were incubated at $37^{\circ} \mathrm{C}$ for three days on an incubator shaker at $200 \mathrm{rpm}$. The crude enzyme was harvested by 
centrifugation at $10,000 \mathrm{~g}$ for $10 \mathrm{~min}$ at $4^{\circ} \mathrm{C}$ and the clear supernatant was used as the source of extracellular phytases. Phytase activity was determined by measuring the amount of liberated inorganic phosphate. The reaction mixture consisted of $0.5 \%$ sodium phytate prepared in $0.2 \mathrm{M}$ sodium acetate buffer, $\mathrm{pH} 5.5$ and $0.2 \mathrm{ml}$ of supernatant. The mixture was then incubated at $37^{\circ} \mathrm{C}$ for 30 minutes and then the reaction was stopped by adding an equal volume of $15 \%$ of trichloroacetic acid. The liberated phosphate ions were quantifies by mixing $0.1 \mathrm{ml}$ of assay mixture with $0.9 \mathrm{ml}$ of $1.0 \mathrm{M} \mathrm{H}_{2} \mathrm{SO}_{4}, 10 \%$ ascorbic acid and $2.5 \%$ ammonium molybdate. After 20 minutes of incubation at $37^{\circ} \mathrm{C}$, absorbance was measured at $820 \mathrm{~nm}$ [16].

\subsection{Colony Morphology}

Colony of each bacterial isolates observed under Stereomicroscope (Leica microscope). The magnification used was $1000 \times$. Each bacterial colony was identified accordingly by margin, elevation and form. Identification of the strains primarily based on the phenotypic characters described in the Bergey's Manual of Systematic Bacteriology [17].

\subsection{Gram Staining}

Gram staining method was done according to [22]. For Gram Staining, a single colony from the plate were picked and placed on a slide. The sample was heat fixed on slide by carefully passing the slide through the Bunsen burner. Then, primary stain which is crystal violet was added to the sample and left for 1 minute. After that, the slide was rinsed carefully for maximum 5 seconds with running tap water. Then, a few drops of Gram's Iodine was added to the slide and left for one minute. After that, the slide was rinsed with alcohol for 3 seconds. Lastly, secondary stain which is safranin was added to the slide and left for one minute and then washed with running tap water for a maximum 5 seconds.

\subsection{Biochemical Test}

Biochemical tests are an analysis of enzymatic functions of the bacterial strains. There were 10 tests carried out in this biochemical characterization. Identification of the strains primarily based on the phenotypic characters described in the Bergey's Manual of Systematic Bacteriology [16-17]. The tests were catalase, oxidase, indole, motility, $\mathrm{H}_{2} \mathrm{~S}$ production, methyl red, voges-proskauer, urease, triple sugar iron (TSI) and growth on MacConkey agar.

\subsection{Extraction of Genomic DNA from Bacteria Isolates}

The putative bacteria strains were cultured in Luria bertani broth and incubated overnight at 
$37^{\circ} \mathrm{C}$ in an orbital shaker at $150 \mathrm{rpm}$. Genomic DNA was extracted using Wizard ${ }^{\circledR}$ Genomic DNA Purification Kit (Promega). Concentration of DNA was measured using Biospectrometer and DNA was visualized using 1\% agarose gel electrophoresis.

\subsection{Phylogenetic Analysis of $16 \mathrm{~S}$ rRNA Gene Sequence}

Universal primers used were FD1 5' CCC AAT TCG TCG ACA ACA GAG TTT GAT CCT GGC TCA G 3' and RD1 5' CCC GGG ATC CAA GCT TAA GCA GGT GAT CCA GCC 3' were used for amplification of $16 \mathrm{~S}$ rRNA gene from the samples. PCR amplification was carried out in a PCR thermal cycler (Applied Biosystems). The PCR reaction mixtures contained $2 \mathrm{mM} \mathrm{MgCl}_{2}, 200 \mu \mathrm{M}$ dNTP, $1 \mathrm{U}$ Taq DNA Polymerase (Promega), $1 \mu \mathrm{g}$ template DNA and $0.5 \mu \mathrm{M}$ forward and reverse primer. Typically, 30 cycles of amplification reactions were conducted according to the following parameters: 5 minutes for initial denaturation at $96^{\circ} \mathrm{C} ; 30$ cycles for 1 minute at $95^{\circ} \mathrm{C}, 2$ minutes at $60^{\circ} \mathrm{C}, 2$ minutes at $72^{\circ} \mathrm{C}$ and a final cycle for 5 minutes at $72^{\circ} \mathrm{C}$ for final extension. A negative control was also loaded to eliminate the possibility of reagent contamination. PCR products stained with GelRed were analysed using 1\% agarose gel and visualized under gel documentation system (Applied Biosystems).

PCR products were sent for sequencing service at First Base Laboratory Sdn. Bhd. and comparison of these sequences were carried out using available database at National Centre for Biotechnology Information (NCBI) using BLAST program (http;//www.ncbi.nlm.nih/gov). Based on maximum identity score, first 10 sequences were selected and aligned using multiple alignment software program (Clustal Omega) to construct phylogenetic tree using Clustal W2 software. The relatedness between the species was calculated by evolutionary distance and represented in the form of phylogenetic tree.

\section{CONCLUSION}

From all the sampling sites; Ranau (Sabah), Ulu Lengong (Kedah), Dusun Tua (Selangor) and Labis (Johor) only five bacteria strains (A, B, D3, L3 and RT) were tested positive for phytase producers by using phytase screening media (PSM). All five isolates were found to have different ability in phytate degradation and they produces either different amount of phtate-degrading ability or their enzymes had different catalytic activity. Bacteria strain L3 
release maximum phytase activity $(>0.16 \mathrm{U} / \mathrm{ml})$ in media without peptone. Characterization of strain L3 via morphology, biochemical tests were successfully carried out. Further 16S rRNA identification has successfully identified the strain as Acinetobacter baumannii with $99 \%$ similarity index.

\section{ACKNOWLEDGEMENTS}

The authors would like to thank to Universiti Sultan Zainal Abidin (UniSZA) for providing fund, facilities and support throughout this study. Special thanks to Mr Noor Muzamil Mohamad for his assistance in this project.

\section{REFERENCES}

[1] Lott J N, Ockenden I, Raboy V, Batten G D. Phytic acid and phosphorus in crop seeds and fruits: A global estimate. Seed Science Research, 2000, 10(1):11-33

[2] Barnett G M. Phosphorus forms in animal manure. Bioresource Technology, 1994, 49(2):139-147

[3] Jorquera M, Martínez O S, Maruyama F, Marschner P, de la Luz Mora M. Current and future biotechnological applications of bacterial phytases and phytase-producing bacteria. Microbes and Environments, 2008, 23(3):182-191

[4] Richardson A E, Barea J M, McNeill A M, Prigent-Combaret C. Acquisition of phosphorus and nitrogen in the rhizosphere and plant growth promotion by microorganisms. Plant and Soil, 2009, 321(1-2):305-339

[5] Hayes J E, Simpson R J, Richardson A E. The growth and phosphorus utilisation of plants in sterile media when supplied with inositol hexaphosphate, glucose 1-phosphate or inorganic phosphate. Plant and Soil, 2000, 220(1-2):165-174

[6] Dev S S, Nisha E A, Venu A. Biochemical and molecular characterization of efficient phytase producing bacterial isolates from soil samples. International Journal of Current Microbiology and Applied Sciences, 2016, 5(5):218-226

[7] Ullah A H, Phllllppy B Q. Immobilization of aspergillus ficuum phktase: Product characterization of this bioreactor. Preparative Biochemistry, 1988, 18(4):483-489 
[8] Greiner R, Konietzny U, Jany K D. Purification and characterization of two phytases from Escherichia coli. Archives of Biochemistry and Biophysics, 1993, 303(1):107-113

[9] Singh N K, Joshi D K, Gupta R K. Isolation of phytase producing bacteria and optimization of phytase production parameters. Jundishapur Journal of Microbiology, 2013, $6(5): 1-7$

[10] Gautam P, Sabu A, Pandey A, Szakacs G, Soccol C R. Microbial production of extra-cellular phytase using polystyrene as inert solid support. Bioresource Technology, 2002, 83(3):229-233

[11] Greiner R. Purification and properties of a phytate-degrading enzyme from Pantoea agglomerans. The Protein Journal, 2004, 23(8):567-576

[12] Unno Y, Okubo K, Wasaki J, Shinano T, Osaki M. Plant growth promotion abilities and microscale bacterial dynamics in the rhizosphere of Lupin analysed by phytate utilization ability. Environmental Microbiology, 2005, 7(3):396-404

[13] Greiner R, Konietzny U. Phytase for food application. Food Technology and Biotechnology, 2006, 44(2):125-140

[14] Alconada T M, Martinez M J. Purification and characterization of a $\beta$-glucosidase from the phytopathogenic fungus Fusarium oxysporum f. sp. melonis. Letters in Applied Microbiology, 1996, 22(2):106-110

[15] Ugwuanyi J O, McNeil B, Harvey L M. Production of protein-enriched feed using agro-industrial residues as substrates. In P. S. N. Nigam, \& A. Pandey (Eds.), Biotechnology for agro-industrial residues utilization. Dordrecht: Springer, 2009, pp. 77-103

[16] Mittal A, Singh G, Goyal V, Yadav A, Aggarwal N K. Optimization of medium components for phytase production on orange peel flour by Klebsiella sp. DB3 using response surface methodology. Innovative Romanian Food Biotechnology, 2011, 9:35-44

[17] Holt J. G., Krieg N. R., Sneath P. H. A., Staley J. T., Williams S. T. Bergey's manual of determinative bacteriology. Baltimore: Williams and Wilkins, 1994

[18] Constantiniu S, Romaniuc A, Iancu LS, Filimon R, Taraşi I. Cultural and biochemical characteristics of Acinetobacter spp. strains isolated from hospital units. Journal of Preventive Medicine, 2004, 12(3-4):35-42

[19] Rath C C, Subramanyam V R. Isolation of thermophilic bacteria from hot springs of 
Orissa, India. Geobios, 1998, 25(2-3):113-119

[20] Demirkan E, Baygın E, Usta A. Screening of phytate hydrolysis Bacillus sp. isolated from soil and optimization of the certain nutritional and physical parameters on the production of phytase. Turkish Journal of Biochemistry/Turk Biyokimya Dergisi, 2014, 39(2):206-214 [21] Mohamad N M, Ali A M, Salleh H M. Carbon sources utilization profiles of thermophilic phytase producing bacteria isolated from hot-spring in Malaysia. International Journal of Biological, Biomolecular, Agricultural, Food and Biotechnological Engineering, 2012, 6(4):131-134

[22] Bartholomew J W, Finkelstein H. Relationship of cell wall staining to gram differentiation. Journal of Bacteriology, 1958, 75(1):77-84

\section{How to cite this article:}

Alias N, Shunmugam S, Ong PY.Isolation and molecular characterization of phytase producing bacteria from malaysia hot springs. J. Fundam. Appl. Sci., 2017, 9(2S), 852-865. 